Article

\title{
Simultaneous LC/MS Analysis of Carotenoids and Fat-Soluble Vitamins in Costa Rican Avocados (Persea americana Mill.)
}

\author{
Carolina Cortés-Herrera ${ }^{1, *}$, Andrea Chacón ${ }^{1}$, Graciela Artavia ${ }^{1}$ and \\ Fabio Granados-Chinchilla ${ }^{2}$ D \\ 1 Centro Nacional de Ciencia y Tecnología de Alimentos, Universidad de Costa Rica, Ciudad Universitaria \\ Rodrigo Facio, 11501-2060 San José, Costa Rica; andrea28.chacon@gmail.com (A.C.); \\ graciela.artavia@ucr.ac.cr (G.A.) \\ 2 Centro de Investigación en Nutrición Animal (CINA), Universidad de Costa Rica, Ciudad Universitaria \\ Rodrigo Facio, 11501-2060 San José, Costa Rica; fabio.granados@ucr.ac.cr \\ * Correspondence: carolina.cortesherrera@ucr.ac.cr; Tel.: +506-2511-7226
}

Academic Editor: Severina Pacifico

Received: 26 August 2019; Accepted: 5 October 2019; Published: 10 December 2019

check for updates

\begin{abstract}
Avocado (a fruit that represents a billion-dollar industry) has become a relevant crop in global trade. The benefits of eating avocados have also been thoroughly described as they contain important nutrients needed to ensure biological functions. For example, avocados contain considerable amounts of vitamins and other phytonutrients, such as carotenoids (e.g., $\beta$-carotene), which are fat-soluble. Hence, there is a need to assess accurately these types of compounds. Herein we describe a method that chromatographically separates commercial standard solutions containing both fat-soluble vitamins (vitamin A acetate and palmitate, Vitamin $\mathrm{D}_{2}$ and $\mathrm{D}_{3}$, vitamin $\mathrm{K}_{1}, \alpha-, \delta-$, and $\gamma$-vitamin $\mathrm{E}$ isomers) and carotenoids ( $\beta$-cryptoxanthin, zeaxanthin, lutein, $\beta$-carotene, and lycopene) effectively (i.e., analytical recoveries ranging from $80.43 \%$ to $117.02 \%$, for vitamins, and from $43.80 \%$ to $108.63 \%$ ). We optimized saponification conditions and settled at $80^{\circ} \mathrm{C}$ using $1 \mathrm{mmol} \mathrm{KOH} \mathrm{L}^{-1}$ ethanol during $1 \mathrm{~h}$. We used a non-aqueous gradient that included methanol and methyl tert-butyl ether (starting at an 80:20 ratio) and a $\mathrm{C}_{30}$ chromatographic column to achieve analyte separation (in less than $40 \mathrm{~min}$ ) and applied this method to avocado, a fruit that characteristically contains both types of compounds. We obtained a method with good linearity at the mid to low range of the $\mathrm{mg} \mathrm{L}^{-1}$ (determination coefficients 0.9006-0.9964). To determine both types of compounds in avocado, we developed and validated for the simultaneous analysis of carotenoids and fat-soluble vitamins based on liquid chromatography and single quadrupole mass detection (LC/MS). From actual avocado samples, we found relevant concentrations for cholecalciferol (ranging from 103.5 to 119.5), $\delta$-tocopherol (ranging from 6.16 to 42.48 ), and lutein (ranging from 6.41 to $15.13 \mathrm{mg} / 100 \mathrm{~g}$ dry weight basis). Simmonds cultivar demonstrated the higher values for all analytes (ranging from 0.03 (zeaxanthin) to 119.5 (cholecalciferol) $\mathrm{mg} / 100 \mathrm{~g}$ dry weight basis).
\end{abstract}

Keywords: avocado; LC/MS; fat-soluble vitamins; carotenoids

\section{Introduction}

Avocado represents a billion-dollar industry, the projection of the apparent per capita consumption of avocado sets the top six world importers of avocado to be US, Netherlands, France, United Kingdom, Spain, and Canada with 3.64, 1.62, 2.10, 2.21, 2.30, and $2.55 \mathrm{~kg}$ in a given year, respectively [1]. Avocado exports have made some countries like Mexico, Dominican Republic, Peru, Chile, Colombia, and Costa Rica increase their cultivated area [1]. 
The topmost exporter countries have directed their offer to destinations such as the US, Europe, and Asia, especially China [2], where import growth is in the order of 250\%, from 154 tons in 2012, to 25,000 tons in 2016 [3,4]. For example, Costa Rican avocado harvested area was estimated at 1888 ha in 2014 and increased to 3092 ha in 2017, which represents 845 tons of Costa Rican avocado (or 448900 USD) [5].

As a complex matrix, performing chemical analysis on the avocado flesh presents an additional difficulty. The ripe avocado fruit has a firm, oily, and yellow to light green colored mesocarp that contains both fat-soluble vitamins and carotenoids associated with other lipids [6]. Usually, both types of analysis have to be performed separately using different chromatographic conditions altogether, which represents an additional expense, both economic and in terms of labor. Analyzing both types of fat-soluble compounds is relevant, especially in fruits such as avocado in which there is evidence that carotenoid absorption might be improved by the addition of avocado and avocado oil [7-9].

Interestingly, the Association of Official Analytical Chemists (AOAC) Official Methods of Analysis $\left(\mathrm{OMA}^{\mathrm{SM}}\right)$ does not have any method established for neither fat-soluble vitamins nor carotenoids in fruits. Several papers have already annotated the relevance of including avocado in the diet as it has been related to health benefits [10-19]. Previously, another report analyzed carotenoid content in avocado using spectrophotometry [20]. A later report has used a similar approach to measure total carotenoid content [21]. On another hand, a research group has analyzed avocado pigments in oil [22] and tissue [22,23] using HPLC coupled with a photodiode array detector using a triphasic organic solvent gradient. Carotenoids in avocado seed have also been described [24,25].

The application of chromatography and mass spectrometry to carotenoid analysis in fruits is not new $[23,26,27]$. However, few papers have been dedicated solely to the study of both fat-soluble and carotenoid content in avocado fruits. For example, research assayed both types of compounds (i.e., carotenoids and tocopherol) using two independent chromatographic techniques [28].

Among the papers dedicated to assessing specifically carotenoids or vitamins in avocado, the most relevant include advantages such as that most researchers use acetone (a versatile and low boiling point solvent) during primary extraction [22,23,28,29] and ethyl ether or hexane after saponification [22,23,29]. For saponification at room temperature, the use of 2,6-di-tert-butyl-4-methylphenol, and nitrogen flushing seems to be a norm [28,29], thus protecting the target analytes. Diversity of carotenoids studies is ample (including epoxides [28], isomers of carotene [20], chlorophylls [22], phytoene [23]). Mobile phases are usually simple and environmentally friendly [22,23,29], which include methanol, water, methyl tert-butyl ether, and ethyl acetate. Yano and coworkers were able to apply their method to 75 and 15 different fresh and processed fruits, respectively [23]. Solid-phase extraction has been used to reduce interferences [22]. Mass spectrometry has been used to recognize unidentified compounds [20,28].

Disadvantages of these methods include the presence of water in the mobile phase (which increases mobile phase polarity), several approaches exhibit some issues with chromatographic resolution for some of the signals [28,29] and in some cases saponification time [29], base concentration [29], and chromatographic run [23] are excessive or the identification of compounds is based on light absorption [20,22,29]. Finally, vitamin analysis of the fruit is scarce at best [11,28].

Lastly, very little information has been gathered regarding varieties of Costa Rican avocados, proximate analysis, mineral content, and some vitamins have been explored [30]. Some papers have also focused on standing out differences between avocado varieties [21,28], including varieties of Guatemalan race (e.g., Hass [11] and Nabal [20]), as avocadoes originated from New Zealand [22], California [28], and Mexico [29] and those commercially available from Israel [20] and Japan [23].

Herein, we report a liquid chromatography and single quadrupole mass detection (LC/MS) based method using a $C_{30}$ column and methanol and methyl tert-butyl ether to assay and quantitatively separate both fat-soluble vitamins (vitamin $A$ acetate and palmitate, Vitamin $\mathrm{D}_{2}$ and $\mathrm{D}_{3}$, vitamin $\mathrm{K}_{1}$, $\alpha-, \delta$-, and $\gamma$-vitamin E isomers) and carotenoids ( $\beta$-cryptoxanthin, zeaxanthin, lutein, $\beta$-carotene, and lycopene) simultaneously in avocado fruit. 


\section{Results and Discussion}

\subsection{Stationary Phase Selection and Green Chemistry}

Where other alkyl modified stationary phases failed (Table 1), the $C_{30}$ allowed an excellent separation of fat-soluble compounds even between structurally related molecules using a $\mathrm{MeOH} /$ tert-butyl methyl ether (MTBE)-based mobile phase (Table 2). The solvent selection not only ensured good compound solubility and chromatographic separation, but it also helped improve column life span as no water was involved and the column could be safely stored under $80 \% \mathrm{MeOH}$.

Table 1. Performance of other stationary phases and conditions tested to try to separate calciferol and tocopherol isomers.

\begin{tabular}{|c|c|c|c|c|c|c|}
\hline Stationary Phase & \multicolumn{2}{|c|}{$\mathrm{C}_{8}$} & \multicolumn{2}{|c|}{$\mathrm{C}_{18}$} & \multicolumn{2}{|c|}{$\mathrm{C}_{30}$} \\
\hline Solvent System & \multicolumn{2}{|c|}{ 95:5 MeOH: $\mathrm{H}_{2} \mathrm{O}$} & \multicolumn{2}{|c|}{ 95:5 MeOH: $\mathrm{H}_{2} \mathrm{O}$} & \multicolumn{2}{|c|}{$\begin{array}{c}90: 7: 3 \\
\mathrm{MeOH}: \mathrm{CH}_{3} \mathrm{CN}: 2-\text { propanol }\end{array}$} \\
\hline Flow, $\mathrm{mL} \min ^{-1}$ & \multicolumn{2}{|c|}{0.75} & \multicolumn{2}{|c|}{1.00} & \multicolumn{2}{|c|}{0.50} \\
\hline Temperature, ${ }^{\circ} \mathrm{C}$ & \multicolumn{2}{|c|}{50} & \multicolumn{2}{|c|}{50} & \multicolumn{2}{|c|}{35} \\
\hline Compound & $t_{R}, \min$ & $\mathrm{R}_{\mathrm{s}}$ & $t_{R}, \min$ & $\mathrm{R}_{\mathrm{s}}$ & $t_{R}, \min$ & $\mathrm{R}_{\mathrm{s}}$ \\
\hline Retinyl acetate & 3.50 & & 4.75 & & 5.42 & \\
\hline Ergocalciferol & 4.74 & 0 & 8.41 & & 8.96 & 0.78 \\
\hline Cholecalciferol & 4.74 & 0 & 8.81 & 1.12 & 9.27 & 0.78 \\
\hline$\delta$-tocopherol & 4.67 & 1.47 & 8.05 & 1.20 & 7.42 & 2.96 \\
\hline$\gamma$-tocopherol & 5.17 & 1.47 & 9.52 & 2.07 & 8.28 & 1.85 \\
\hline$\alpha$-tocopherol & 7.05 & & 15.14 & & 12.19 & \\
\hline Phylloquinone & 7.84 & & 19.87 & & 13.17 & \\
\hline Retinyl palmitate & 13.09 & & 48.33 & & 35.22 & \\
\hline
\end{tabular}

Table 2. Optimized Mass Spectrometry (MS) parameters for the assayed compounds, in order of $m / z$.

\begin{tabular}{|c|c|c|c|c|c|}
\hline $\begin{array}{l}\text { Detector Set } \\
\text { Time, min }\end{array}$ & Compound & $t_{R}, \min$ & Selected SIM Ion, $m / z$ & Fragmentor, V & Dwell Time, ms \\
\hline \multirow{3}{*}{ From 0 to 5} & Retinyl acetate & 2.99 & $\begin{array}{c}269.3\left[\mathrm{C}_{20} \mathrm{H}_{29}\right]^{\bullet+} / 325.2 \\
{\left[\mathrm{C}_{20} \mathrm{H}_{29} \mathrm{OH}+\mathrm{K}\right]^{+}}\end{array}$ & 100 & \multirow{3}{*}{95} \\
\hline & Ergocalciferol & 3.59 & $398.3[\mathrm{M}+\mathrm{H}]^{+}$ & 220 & \\
\hline & Cholecalciferol & 4.02 & $385.3[\mathrm{M}+\mathrm{H}]^{+}$ & 160 & \\
\hline \multirow{3}{*}{ From 5 to 8} & $\delta$-tocopherol & 5.26 & $402.5[\mathrm{M}+]$ & 220 & \multirow{3}{*}{71} \\
\hline & $\gamma$-tocopherol & 5.78 & $416.4[\mathrm{M}+]$ & 140 & \\
\hline & $\alpha$-tocopherol & 6.61 & $430.4[\mathrm{M}+]$ & 80 & \\
\hline \multirow{4}{*}{ From 8 to 13} & Phylloquinone & 8.07 & $451.4[\mathrm{M}+\mathrm{H}]^{+}$ & 140 & \multirow{4}{*}{56} \\
\hline & Astaxanthin & 9.07 & $597.4[\mathrm{M}+\mathrm{H}]^{+}$ & 160 & \\
\hline & Lutein & 9.97 & $569.4[\mathrm{M}+\mathrm{H}]^{+}$ & 140 & \\
\hline & Zeaxanthin & 11.49 & $568.4[\mathrm{M}+]$ & 140 & \\
\hline \multirow{4}{*}{ After 13} & $\begin{array}{l}\text { Retinyl } \\
\text { palmitate }\end{array}$ & 11.19 & $\begin{array}{c}269.3\left[\mathrm{C}_{20} \mathrm{H}_{29}\right]^{\bullet+} / 563.4 \\
{[\mathrm{M}+\mathrm{K}]^{+}}\end{array}$ & 100 & \multirow{4}{*}{95} \\
\hline & $\beta$-cryptoxanthin & 16.58 & $552.6[\mathrm{M}+]$ & 120 & \\
\hline & $\beta$-carotene & 22.51 & $536.4[\mathrm{M}+]$ & 120 & \\
\hline & Lycopene & 37.39 & $536.1[\mathrm{M}+]$ & 160 & \\
\hline
\end{tabular}

Some methods have selected chlorinated solvents as an effective way to extract [28] or separate carotenoids [31]. However, we chose MTBE as a greener alternative to chlorinated solvents [32]. Additionally, our chromatographic separation was mostly based on $\mathrm{MeOH}$. The high degree of shape recognition of the $C_{30}$ was validated early [33] and was, once again, here, demonstrated. It is recommended for analysis of retinoid as well as carotenoid molecules [34]. However, herein, we exploited the versatility of the $C_{30}$ column further. Furthermore, as avocado lacks the presence of 
lycopene [20,28], this compound when introduced into the separation (especially in its deuterated form), can be used as an internal standard (IS). Though lycopene is considered a relative liable carotenoid, it has been used successfully as an IS [35]. Other more stable molecules have been used as well and could be considered (e.g., canthaxanthin [35], sudan I [36]; $8^{\prime}$-apo- $8^{\prime}$ - $\beta$-carotenal [37], echinenone [38]).

\subsection{Singular Ion Monitoring Parameter Selection}

As expected, using reverse phase chromatography, fat-soluble vitamins eluted during the first 8 min (except for retinyl palmitate, an esterified compound with an extra $C_{15}$ alkyl chain) (Table 2). Both retinoids assessed were prone to retain monovalent cations such as $\mathrm{K}^{+}\left([\mathrm{M}+\mathrm{K}]^{+}\right)$. Retinyl acetate and retinyl palmitate share a similar fragmentation pattern, which includes ion $269 \mathrm{~m} / \mathrm{z}$ as a base peak (Table 2). The retinoid alkyl chain did not seem to affect ionization voltage, indicating that the $\mathrm{C}_{20} \mathrm{H}_{29} \mathrm{OH}$ base was governing their behavior. Ion $296 \mathrm{~m} / \mathrm{z}$ found for retinoids corresponded to the protonation and elimination of water and acetate during positive ion electrospray [34].

All tocopherol isomers, as well as zeaxanthin, $\beta$-cryptoxanthin, $\beta$-carotene, and lycopene (the heavier analogs), exhibited deprotonated species as molecular ions $([\mathrm{M}+])$. Electrospray ionization $\left(\mathrm{ESI}^{+}\right)$ions are usually preformed in solution by acid/base reactions (i.e., $[\mathrm{M}+\mathrm{nH}]^{\mathrm{n}+}$ ), some ions are probably formed by a field desorption mechanism at the surface. Hence, the production of abundant cations, with little fragmentation [34]. Meanwhile, phylloquinone, the acidic carotenoid astaxanthin [34], and lutein all ionized through protonated species $\left([\mathrm{M}+\mathrm{H}]^{+}\right)$(Table 2). Interestingly, the highly related compounds $\alpha_{-}^{-}, \gamma^{-}$, and $\beta$-tocopherols exhibited very different ionization energies (i.e., 80, 140, and $220 \mathrm{~V}$, respectively) (Table 2).

\subsection{Method Performance Data}

For the vitamin group, the higher sensitivity was exhibited by $\alpha_{-}^{-}, \gamma_{-}^{-}$, and retinyl palmitate (Table 2). On the other hand, carotenoids with a lower limit of detection were astaxanthin, lutein, and zeaxanthin (Table 3). Electrospray analysis of carotenoids, since some years ago, has demonstrated high sensitivity (i.e., in the pmol range) [39]. These compounds, as expressed in the matrix of interest, could be detected as low as $1 \mu \mathrm{g} / 100 \mathrm{~g}$ dry matter (Table 3). The resolution obtained between the compounds analyzed ranged from 2.18-71.90; the lowest value recommended is 2 (Table 2, Figure 1A) [40]. Several compounds were very close to the theoretical value of 1 (i.e., a perfect peak with a Gaussian distribution and completely symmetrical) though ergocalciferol (1.707), and lutein (1.348) exhibited some tailing. Fronting (leading peak) can also be observed for retinyl acetate (0.709) (Table 3). Column efficiency was very high for compounds eluted above $8 \mathrm{~min}$, such as phylloquinone, zeaxanthin, retinyl palmitate, $\beta$-cryptoxanthin, and $\beta$-carotene (Table 3 ). A good baseline definition was observed for all compounds analyzed (i.e., $\alpha_{\mathrm{s}}$ ranging from 1.07 to 1.76) (Table 3).

Table 3. Method performance parameters obtained during validation.

\begin{tabular}{|c|c|c|c|c|c|c|}
\hline \multicolumn{7}{|c|}{ Sensitivity } \\
\hline Compound & LoD, $\mu \mathrm{g} \mathrm{L}^{-1}$ & LoQ, $\mu \mathrm{g} \mathrm{L}^{-1}$ & $\begin{array}{c}\text { LoD, } \mu g / 100 \mathrm{~g} \\
\text { fat }\end{array}$ & $\begin{array}{c}\text { LoQ, } \\
\mu \mathrm{g} / 100 \mathrm{~g} \text { fat }\end{array}$ & $\begin{array}{c}\text { LoD, } \mu \mathrm{g} / 100 \mathrm{~g} \\
\text { dry matter }\end{array}$ & $\begin{array}{c}\text { LoQ, } \mu \mathrm{g} / 100 \mathrm{~g} \\
\text { dry matter }\end{array}$ \\
\hline $\begin{array}{l}\text { Retinyl } \\
\text { acetate }\end{array}$ & $3.00 \times 10^{2}$ & $9.20 \times 10^{2}$ & $1.00 \times 10^{2}$ & $3.07 \times 10^{2}$ & $1.50 \times 10^{1}$ & $4.60 \times 10^{1}$ \\
\hline Ergocalciferol & $1.00 \times 10^{2}$ & $2.90 \times 10^{2}$ & $3.30 \times 10^{1}$ & $9.70 \times 10^{1}$ & $0.50 \times 10^{1}$ & $1.50 \times 10^{1}$ \\
\hline Cholecalciferol & $2.70 \times 10^{2}$ & $8.20 \times 10^{2}$ & $9.00 \times 10^{1}$ & $2.73 \times 10^{2}$ & $1.40 \times 10^{1}$ & $4.10 \times 10^{1}$ \\
\hline$\delta$-tocopherol & $1.70 \times 10^{2}$ & $5.10 \times 10^{2}$ & $5.70 \times 10^{1}$ & $1.70 \times 10^{2}$ & $0.90 \times 10^{1}$ & $2.60 \times 10^{1}$ \\
\hline$\gamma$-tocopherol & $1.30 \times 10^{1}$ & $3.80 \times 10^{1}$ & $0.40 \times 10^{1}$ & $1.30 \times 10^{1}$ & $0.10 \times 10^{1}$ & $0.20 \times 10^{1}$ \\
\hline$\alpha$-tocopherol & $0.70 \times 10^{1}$ & $2.40 \times 10^{1}$ & $0.20 \times 10^{1}$ & $0.80 \times 10^{1}$ & $0.10 \times 10^{1}$ & $0.10 \times 10^{1}$ \\
\hline Phylloquinone & $4.30 \times 10^{2}$ & $1.29 \times 10^{3}$ & $1.43 \times 10^{2}$ & $4.30 \times 10^{2}$ & $2.20 \times 10^{1}$ & $6.50 \times 10^{1}$ \\
\hline Astaxanthin & $2.20 \times 10^{1}$ & $1.25 \times 10^{2}$ & $0.70 \times 10^{1}$ & $4.20 \times 10^{1}$ & $0.10 \times 10^{1}$ & $0.60 \times 10^{1}$ \\
\hline Lutein & $1.00 \times 10^{1}$ & $2.90 \times 10^{1}$ & $0.30 \times 10^{1}$ & $1.00 \times 10^{1}$ & $0.10 \times 10^{1}$ & $0.10 \times 10^{1}$ \\
\hline Zeaxanthin & $0.90 \times 10^{1}$ & $2.80 \times 10^{1}$ & $0.30 \times 10^{1}$ & $0.90 \times 10^{1}$ & $0.10 \times 10^{1}$ & $0.10 \times 10^{1}$ \\
\hline
\end{tabular}


Table 3. Cont

\begin{tabular}{|c|c|c|c|c|c|c|c|c|c|c|}
\hline $\begin{array}{l}\text { Retinyl } \\
\text { palmitate }\end{array}$ & \multicolumn{2}{|c|}{$2.40 \times 10^{1}$} & $7.40 \times 10^{2}$ & \multicolumn{2}{|c|}{$0.80 \times 10^{1}$} & \multicolumn{2}{|c|}{$2.47 \times 10^{2}$} & \multicolumn{2}{|l|}{$0.10 \times 10^{1}$} & $3.70 \times 10^{1}$ \\
\hline$\beta$-cryptoxanthin & \multicolumn{2}{|c|}{$3.30 \times 10^{2}$} & $9.90 \times 10^{2}$ & \multicolumn{2}{|c|}{$1.10 \times 10^{2}$} & \multicolumn{2}{|c|}{$3.30 \times 10^{2}$} & \multicolumn{2}{|l|}{$1.70 \times 10^{1}$} & $5.00 \times 10^{1}$ \\
\hline$\beta$-carotene & \multicolumn{2}{|c|}{$8.80 \times 10^{2}$} & $2.67 \times 10^{3}$ & \multicolumn{2}{|c|}{$2.93 \times 10^{2}$} & \multicolumn{2}{|c|}{$8.90 \times 10^{2}$} & \multicolumn{2}{|l|}{$4.40 \times 10^{1}$} & $1.34 \times 10^{2}$ \\
\hline Lycopene & $1.56 \times$ & & $4.71 \times 10^{2}$ & \multicolumn{2}{|c|}{$\begin{array}{r}5.20 \times 10^{1} \\
\text { Sensitivity }\end{array}$} & \multicolumn{2}{|c|}{$1.57 \times 10^{2}$} & $0.80 \times 10^{1}$ & \multicolumn{2}{|r|}{$2.40 \times 10^{1}$} \\
\hline Compound & \multicolumn{2}{|c|}{ LoD, $\mu \mathrm{g} \mathrm{L}^{-1}$} & $\mathrm{LoQ}, \mu \mathrm{g} \mathrm{L}^{-1}$ & \multicolumn{2}{|c|}{$\begin{array}{c}\mathrm{LoD}, \mu \mathrm{g} / 100 \mathrm{~g} \\
\text { fat }\end{array}$} & \multicolumn{2}{|c|}{$\begin{array}{c}\text { LoQ, } \\
\mu \mathrm{g} / 100 \mathrm{~g} \text { fat }\end{array}$} & \multicolumn{2}{|l|}{$\begin{array}{l}\text { LoD, } \mu \mathrm{g} / 100 \mathrm{~g} \\
\text { dry matter }\end{array}$} & $\begin{array}{c}\text { LoQ, } \mu \mathrm{g} / 100 \mathrm{~g} \\
\text { dry matter }\end{array}$ \\
\hline \multicolumn{11}{|c|}{ Chromatographic Parameters } \\
\hline Compound & $t_{R}, \min$ & {$\left[[], \mathrm{mg} \mathrm{L}^{-1}\right.$} & $\begin{array}{l}\text { Area, } \\
\times 10^{5}\end{array}$ & $\begin{array}{l}\text { Height, } \\
\times 10^{4}\end{array}$ & $\begin{array}{c}\text { Peak } \\
\text { Width }\end{array}$ & Symm & $\operatorname{try}_{s}$ & $k$ & $\alpha$ & $\begin{array}{c}N, \\
\times 10^{4} \\
\end{array}$ \\
\hline $\begin{array}{l}\text { Retinyl } \\
\text { acetate }\end{array}$ & 3.00 & 5.00 & 8.98 & 12.96 & 0.12 & 0.71 & 3.67 & 0.35 & 1.61 & 1.08 \\
\hline Ergocalciferol & 3.48 & 0.50 & 5.34 & 5.12 & 0.15 & 1.71 & 3.54 & 0.57 & 1.39 & 0.92 \\
\hline Cholecalciferol & 3.97 & 1.00 & 1.76 & 1.78 & 0.13 & 0.91 & 7.96 & 0.79 & 1.71 & 1.45 \\
\hline$\delta$-tocopherol & 5.21 & 1.00 & 0.67 & 0.63 & 0.18 & 0.95 & 2.85 & 1.35 & 1.16 & 1.34 \\
\hline$\gamma$-tocopherol & 5.71 & 1.00 & 9.07 & 7.65 & 0.17 & 0.77 & 3.52 & 1.57 & 1.22 & 1.87 \\
\hline$\alpha$-tocopherol & 6.49 & 1.00 & 21.99 & 13.27 & 0.28 & 0.99 & 7.20 & 1.92 & 1.33 & 0.88 \\
\hline Phylloquinone & 7.89 & 1.00 & 0.29 & 0.32 & 0.11 & 0.80 & 4.75 & 2.56 & 1.18 & 7.77 \\
\hline Astaxanthin & 8.94 & 0.05 & 0.78 & 0.40 & 0.33 & 0.88 & 2.18 & 3.03 & 1.11 & 1.19 \\
\hline Lutein & 9.68 & 0.05 & 4.19 & 1.95 & 0.36 & 1.35 & 4.59 & 3.37 & 1.19 & 1.17 \\
\hline Zeaxanthin & 11.09 & 1.00 & 0.66 & 0.44 & 0.25 & 1.06 & 2.87 & 3.40 & 1.07 & 3.09 \\
\hline $\begin{array}{c}\text { Retinyl } \\
\text { palmitate }\end{array}$ & 11.75 & 0.20 & 5.68 & 4.52 & 0.21 & 1.08 & 26.91 & 4.30 & 1.49 & 5.03 \\
\hline$\beta$-cryptoxanthin & 16.40 & 0.20 & 0.03 & 0.04 & 0.14 & 0.80 & 27.10 & 6.40 & 1.40 & 23.14 \\
\hline$\beta$-carotene & 22.14 & 1.00 & 0.38 & 0.22 & 0.29 & 0.76 & 71.90 & 8.98 & 1.76 & 9.54 \\
\hline Lycopene & 37.39 & 1.00 & 0.28 & 0.34 & 0.14 & 1.04 & - & - & - & 118.31 \\
\hline
\end{tabular}
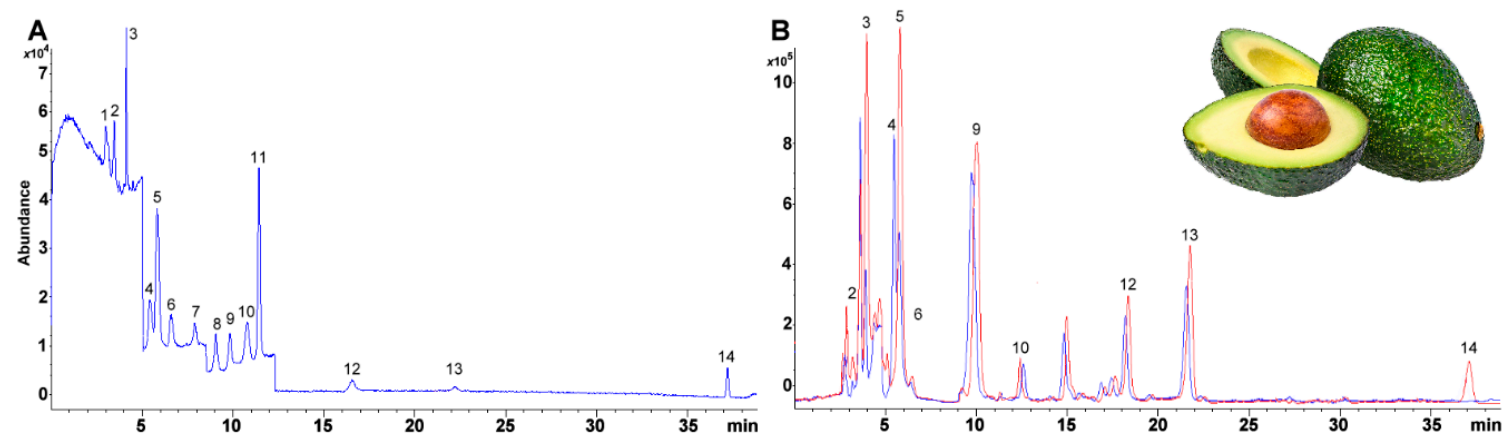

Figure 1. Selected ion monitoring (SIM) chromatogram for (A). (A) A standard mixture of 14 analytes at $1 \mu \mathrm{g} \mathrm{mL}^{-1}$ for liposoluble vitamins and $0.05 \mu \mathrm{g} \mathrm{mL}{ }^{-1}$ for carotenoids. 1. Retinyl acetate. 2. Ergocalciferol. 3. Cholecalciferol. 4. $\delta$-Tocopherol. 5. $\gamma$-Tocopherol. 6. $\alpha$-Tocopherol. 7. Phylloquinone. 8. Astaxanthin. 9. Lutein. 10. Zeaxanthin. 11. Retinyl palmitate. 12. $\beta$-Cryptoxanthin. 13. $\beta$-Carotene. 14. Lycopene. (B) The saponified avocado sample analyzed using the proposed chromatographic method (blue line), and a sample spiked with $5 \mu \mathrm{mol}$ for each vitamin and $1 \mu \mathrm{mol}$ for each carotenoid (red line).

The method was successfully applied to avocado fruits (Figure 2B). The lack of available certified reference materials for matrices such as fruits obliges the use of spike solutions to demonstrate both matrix effects (if any) and extraction efficiency of vitamins and carotenoids in avocado specifically. 

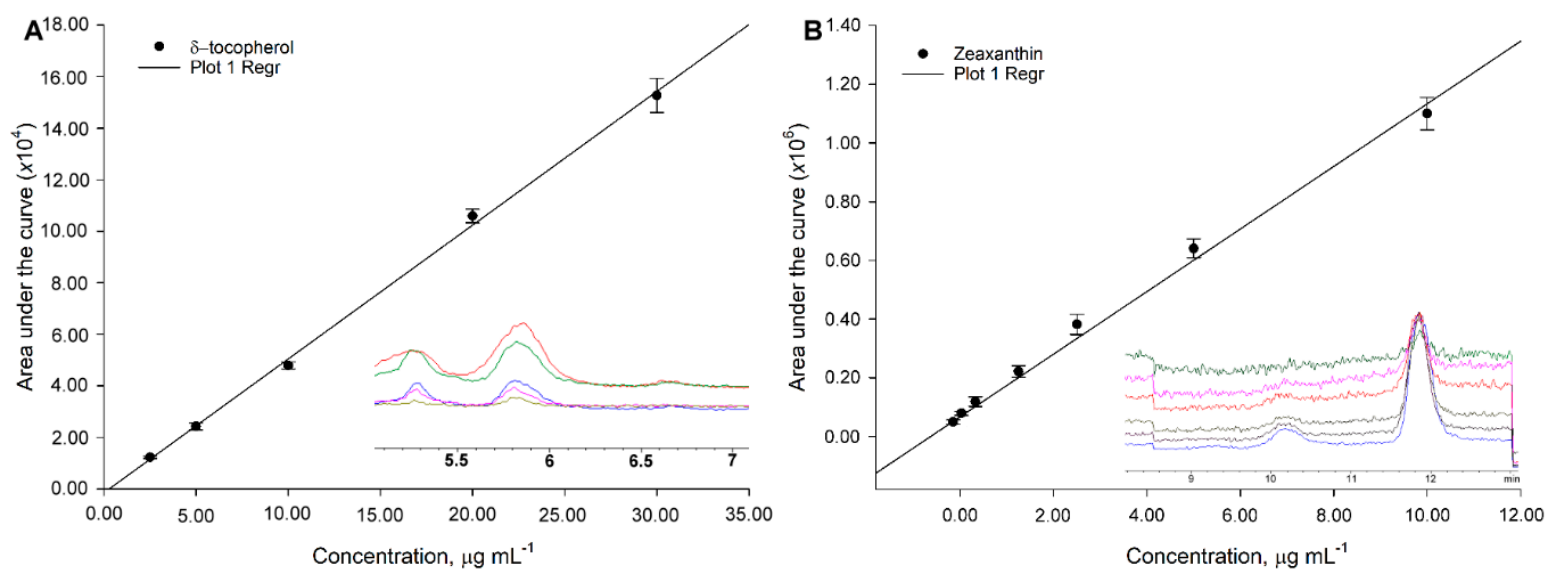

Figure 2. Average calibration curves and error bars depicting variability obtained for two of the target analytes (A) $\delta$-tocopherol and (B) zeaxanthin. Mean and standard deviations (used as error) calculated from $n=3$ independently constructed calibration curves injected on different days.

\subsection{Performance during Saponification}

Saponification-wise, using the same starting mass and sample, we proceeded to optimize the conditions needed (i.e., base concentration and time) to improve analyte recovery. The differential analysis showed that, overall, samples treated at $80{ }^{\circ} \mathrm{C}$ for one hour and using $1 \mathrm{~mol} \mathrm{KOH} \mathrm{L}{ }^{-1}$ exhibited the best results in the case of the analytes of interest, for avocado (Table 4). Variables tested showed a profound and significant effect over analyte recovery $(p<0.05$ for all cases) (Table 4$)$. Reaction parameters must be optimized to ensure proper hydrolysis within the complex, considerably oily (ranging from 35.3 to $39.1 \mathrm{~g}$ fat/100 $\mathrm{g}$ dry weight basis), food matrix that is found in the ripe avocado fruit [41]. Carotenoids are increasingly sensitive to heat. Hence, hot saponification was carried out using an organic solvent with a relatively low boiling point [6] (i.e., $78.37^{\circ} \mathrm{C}$ at Standard Pressure and Temperature [STP] for ethanol) and pyrogallol was used as a radical sink to protect the compounds of interest. However, the improvement in recovery was achieved by increasing the temperature to $80^{\circ} \mathrm{C}$. A procedure that might be justified as (i) the thermal effect must be sufficient to break the cell walls from the avocado fruit and provide a rapid molecular diffusion to promote reaction; (ii) higher temperatures increase solubility of lipophilic compounds and enhance kinetics of saponification (i.e., favors localized "hot spots" which deliver sufficient energy for the molecules to react) [42]. We chose hot saponification to diminish reaction time; a similar approach has been reported elsewhere [43].

Table 4. Optimization of saponification conditions.

\begin{tabular}{|c|c|c|c|c|c|c|c|}
\hline \multirow{2}{*}{\multicolumn{2}{|c|}{$\frac{\text { Temperature, }^{\circ} \mathrm{C}}{\text { Base Concentration, mol KOH L }}$}} & \multicolumn{2}{|c|}{60} & \multicolumn{2}{|c|}{80} & \multicolumn{2}{|c|}{95} \\
\hline & & 1 & 2 & 1 & 2 & 1 & 2 \\
\hline Compound & $t_{R}, \min$ & \multicolumn{6}{|c|}{$\mathrm{mg} / 100 \mathrm{~g}^{\mathrm{a}}$} \\
\hline Ergocalciferol & 3.59 & $18.89(-0.14)$ & $10.98(-0.50)$ & 22.06 & $8.38(-0.62)$ & $1.74(-0.92)$ & $\mathrm{ND}(-1.00)$ \\
\hline$\delta$-tocopherol & 5.26 & $9.65(-0.89)$ & $88.22(-0.02)$ & 90.06 & $67.32(-0.25)$ & $0.24(-1.00)$ & $88.17(-0.02)$ \\
\hline$\gamma$-tocopherol & 5.78 & $0.45(-0.93)$ & $0.50(-0.92)$ & 6.14 & $2.48(-0.60)$ & $0.11(-0.98)$ & $9.62(0.57)$ \\
\hline$\alpha$-tocopherol & 6.61 & $\begin{array}{l}180.96 \\
(-0.32)\end{array}$ & $\begin{array}{l}102.35 \\
(-0.62)\end{array}$ & 267.77 & $90.77(-0.66)$ & $74.00(-0.72)$ & $70.63(-0.74)$ \\
\hline Astaxanthin & 9.07 & $18.69(-0.26)$ & $16.82(-0.33)$ & 25.14 & $17.12(-0.32)$ & $7.64(-0.70)$ & $14.16(-0.44)$ \\
\hline Lutein & 9.97 & $0.08(0.00)$ & $0.07(-0.13)$ & 0.08 & $0.12(0.50)$ & $0.02(-0.75)$ & $0.12(0.50)$ \\
\hline Zeaxanthin & 11.49 & $26.60(-0.13)$ & $37.70(0.23)$ & 30.73 & $47.44(0.54)$ & $7.85(-0.74)$ & $20.38(-0.34)$ \\
\hline$\beta$-cryptoxanthin & 16.58 & $24.66(-0.22)$ & $12.13(-0.61)$ & 31.50 & $27.02(-0.14)$ & $5.54(-0.82)$ & $16.93(-0.46)$ \\
\hline$\beta$-carotene & 22.51 & $18.89(-0.14)$ & $10.98(-0.50)$ & 22.06 & $8.38(-0.62)$ & $1.74(-0.92)$ & ND $(-1.00)$ \\
\hline \multicolumn{2}{|c|}{$p$ values } & 0.044 & 0.040 & - & 0.037 & 0.011 & 0.028 \\
\hline
\end{tabular}

${ }^{\text {a }}$ Brackets indicate bias, expressed as a fraction, with respect to the saponification treatment of $1 \mathrm{~h}$ at $80^{\circ} \mathrm{C}$ using a $1 \mathrm{~mol} \mathrm{~L}-1$ base concentration. ND: not detected. 


\subsection{Quantification, Linearity, and Calibration Curve Construction}

Five-point calibration curves were constructed to quantitate the analytes. Slopes $\left(m_{x}\right)$ ranging from $4.05 \times 10^{3}$ (cholecalciferol) to $5.51 \times 10^{4}$ (ergocalciferol) and $5.45 \times 10^{4}$ ( $\beta$-cryptoxanthin) to $6.49 \times 10^{6}$ (zeaxanthin) for vitamins and carotenoids, respectively, were obtained. Determination coefficients spoke toward excellent linearity ranging from 0.9906 to 0.9964 (Figure 2A,B). For vitamins, standard calibration curves were constructed as follows: from 1.00 to $10.00 \mathrm{mg} \mathrm{L}^{-1}$ for retinyl acetate, ergocalciferol, $\gamma^{-}$, and $\alpha$-tocopherol and retinyl palmitate; from 2.50 to $30.00 \mathrm{mg} \mathrm{L}^{-1}$ for cholecalciferol, $\delta$-tocopherol, and phylloquinone. Finally, considering lower concentrations found in the target matrix and carotenoid sensitivity, standard calibration curves were constructed as follows: 0.05 to $0.80 \mathrm{mg}$ $\mathrm{L}^{-1}$ for astaxanthin, $\beta$-cryptoxanthin, and $\beta$-carotene and from 0.1 to $2 \mathrm{mg} \mathrm{L}^{-1}$ for zeaxanthin and lutein (Figure 2A,B). Concentrated stock solutions were prepared by dissolving the solid standard in 2-propanol for vitamins and chloroform for carotenoids; dilutions performed after that were matched with the mobile phase (i.e., the gradient at the start of the chromatographic run).

\subsection{Analyte Recovery and Method Accuracy}

Overall, vitamin recovery, in spiked avocadoes, exhibited better performance than for carotenoids (except for $\beta$-carotene with a recovery of $108.63 \%$ ). Structurally, the lower recoveries (ranging from $43.80 \%$ to $63.68 \%$ ) were found for those carotenoids that were oxygenated (Table 5). Noteworthy, when zeaxanthin and $\beta$-cryptoxanthin were extracted using a mixture of ethyl ether, and hexane (50:50) obtained/experimental mass increased between $12.35 \%$ and $15.56 \%$. Furthermore, when nitrogen flushing was performed, in conjunction, an additional increment between $13.35 \%$ to $19.66 \%$, was observed (data not shown). Carotenoids, among several mechanisms of transformation [44,45], are susceptible to thermal degradation [46,47], $\beta$-carotene may suffer from symmetrical oxidative cleavage (which generates, the apocarotenoid, retinol) [48], and $\beta$-cryptoxanthin can undergo light-induced oxidation and isomerization [49].

Table 5. Spiked avocado samples and recovery for representatives for fat-soluble vitamins and carotenoids.

\begin{tabular}{ccccc}
\hline \multirow{2}{*}{ Compound } & $\boldsymbol{t}_{\boldsymbol{R}}, \mathbf{m i n}$ & \multicolumn{2}{c}{ Concentration, $\boldsymbol{\mu \text { mol }}$} & \multirow{2}{*}{ Recovery, \% ${ }^{\mathbf{a}}$} \\
\cline { 3 - 4 } & & Theoretical/Added & Experimental/Obtained & \\
\hline Ergocalciferol & 3.59 & $5.00 \times 10^{1}$ & $4.00 \times 10^{1}$ & $81.21(70-110)$ \\
$\alpha$-tocopherol & 6.61 & $4.60 \times 10^{1}$ & $3.70 \times 10^{1}$ & $80.43(70-110)$ \\
Phylloquinone & 8.07 & $3.50 \times 10^{1}$ & $4.20 \times 10^{1}$ & $117.02(70-110)$ \\
Astaxanthin & 9.07 & $1.70 \times 10^{1}$ & $1.00 \times 10^{1}$ & $62.27(60-120)$ \\
Lutein & 9.97 & $0.35 \times 10^{1}$ & $0.23 \times 10^{1}$ & $63.68(60-120)$ \\
Zeaxanthin & 11.49 & $0.23 \times 10^{1}$ & $0.10 \times 10^{1}$ & $43.80(60-120)$ \\
$\beta$-cryptoxanthin & 16.58 & $1.09 \times 10^{2}$ & $6.50 \times 10^{1}$ & $59.51(70-110)$ \\
$\beta$-carotene & 22.51 & $1.23 \times 10^{1}$ & $1.33 \times 10^{1}$ & $108.63(60-120)$ \\
\hline
\end{tabular}

${ }^{a}$ Brackets represent recovery values recommended by AOAC [50].

\subsection{Mass Spectra Analysis}

Retinyl acetate and $\beta$-cryptoxanthin showed, under our conditions, a higher degree of fragmentation compared to tocopherol and an oxygenated carotenoid. Additional to the signals analyzed above for retinoids, ion 369.3 represented the retinyl acetate molecular ion plus a potassium ion, $\left[\mathrm{M}+\mathrm{K}^{+}\right.$(Figure 3A). On another hand, tocopherols usually are characterized to present few fragmentation processes [51] (Figure 3B). Major ions are formed by cleavage through the non-aromatic portion of the chromanol ring, both with and without hydrogen transfer and by a loss of the isoprenoid side chain [51]. In contrast, we found none of the usual fragments reported elsewhere for the fragmentation of $\gamma$-tocopherol (e.g., $\mathrm{C}_{9} \mathrm{H}_{11} \mathrm{O}_{2}{ }^{+} m / z 151 \mathrm{amu}$; [51]) probably because the total 
ion chromatogram was obtained using lower energy than required. Also, there may have been some instrument limitations as a single quadrupole was used throughout the experiments, and the fragmentation ions were the result of molecule degradation in the ion source not in the collision chamber used during tandem mass spectrometry. Hence, the lack of tandem mass detection justified the absence, in some cases, of multiple fragmentation patterns [52]. However, the molecular ion [M+] for $\gamma$-tocopherol was unmistakable and could be used to differentiate nuances among tocopherols (e.g., the difference between $\gamma$-tocopherol and $\alpha$-tocopherol is a methyl group in the aromatic ring ( $\Delta 15 \mathrm{amu})$ ). As an example of calciferol identification, cholecalciferol total ion chromatogram (TIC)-mass spectra showed relevant fragments at 365.1 (loss of $\mathrm{H}_{2} \mathrm{O}$ ), 337.1 (subsequent loss of both $-\mathrm{CH}_{3}$ from the isopropyl moiety), 301.2, and 227.0 (loss of $-\mathrm{CH}_{3}$ and $=\mathrm{CH}_{2}$ or $\mathrm{C}_{17} \mathrm{H}_{23}{ }^{3 \bullet}$ ) $\mathrm{m} / \mathrm{z}$ (data not shown).
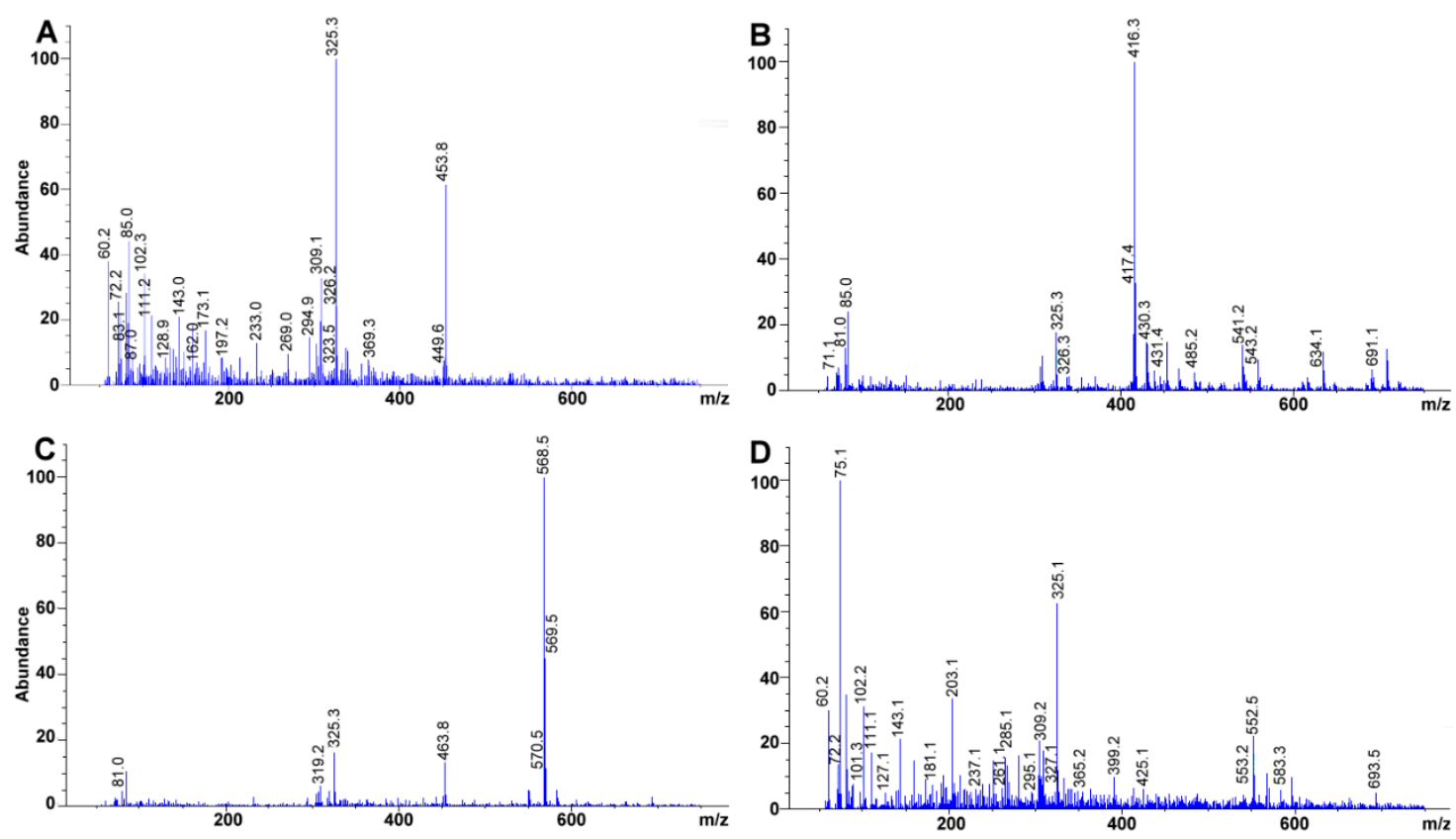

Figure 3. Experimental mass spectra obtained for (A) retinyl acetate, (B) $\gamma$-tocopherol, (C) Lutein, (D) $\beta$-cryptoxanthin. Total ion chromatograms at $100 \mathrm{mg} \mathrm{L}^{-1}$ each.

On another hand, Atmospheric-pressure chemical ionization (APCI), Fast atom bombardment (FAB), electron ionization (EI), and ESI all have mass-based techniques used to assess carotenoids [53]. While APCI is a popular approach for the ionization of lipophilic compounds, we selected $\mathrm{ESI}^{+}$. In this scenario, some modifications were introduced into the mobile phase to enhance ionization. In this specific case, formic acid was selected as it has been described to decrease signal suppression [54]. For the case of lutein the signal $551 \mathrm{~m} / \mathrm{z}$ (i.e., $[\mathrm{M}+\mathrm{H}-18]$ which corresponds to the loss of $\mathrm{H}_{2} \mathrm{O}$ ) and $463 \mathrm{~m} / \mathrm{z}([\mathrm{M}+\mathrm{H}-106]$, loss of two water molecules and xylene from the polyene chain) were observable ([53,55]; Figure 3C). Additionally, as zeaxanthin and lutein differed from each other by a position of a double bond, in a $\varepsilon$-ring, they rendered similar spectra [53]. Further fragmentation for both compounds responded to the loss of said rings. Finally, for $\beta$-cryptoxanthin, signal $552.5([\mathrm{M}+])$ and $553.2 \mathrm{~m} / \mathrm{z}\left([\mathrm{M}+\mathrm{H}]^{+}\right)$were evident, fragments $425.1\left[\mathrm{C}_{32} \mathrm{H}_{40}\right]^{+}$and $399[\mathrm{M}+\mathrm{H}-153]^{+} \mathrm{m} / \mathrm{z}$ responded to the partial breakup of both $\beta$-rings and the complete loss of the oxygenated $\beta$-ring plus a methyl group (Figure 3D).

\subsection{Chromatographic Separation of Tocopherol Isomers}

Under our chromatographic conditions, tocopherol isomers were easily segregated (Figure 4A). Using the tocopherol mixture containing $\alpha-, \beta-, \delta-$, and $\gamma$-tocopherols, we were able to assess further that no additional $[\mathrm{M}+]$ signal was necessary for the detection of $\beta$-tocopherol, as $\beta$ - and $\gamma$-tocopherol 
share the same molecular mass (Figure $4 \mathrm{~B}, \mathrm{C}$ ). The signal for $\beta$-tocopherol was observed at a $t_{R}$ of $5.387 \mathrm{~min}$ (Figure 4A). Hence, the four tocopherol isomers eluted as follows: $\delta-, \beta-, \gamma-$, and $\alpha$-tocopherol (Table 1, Figure 4A).
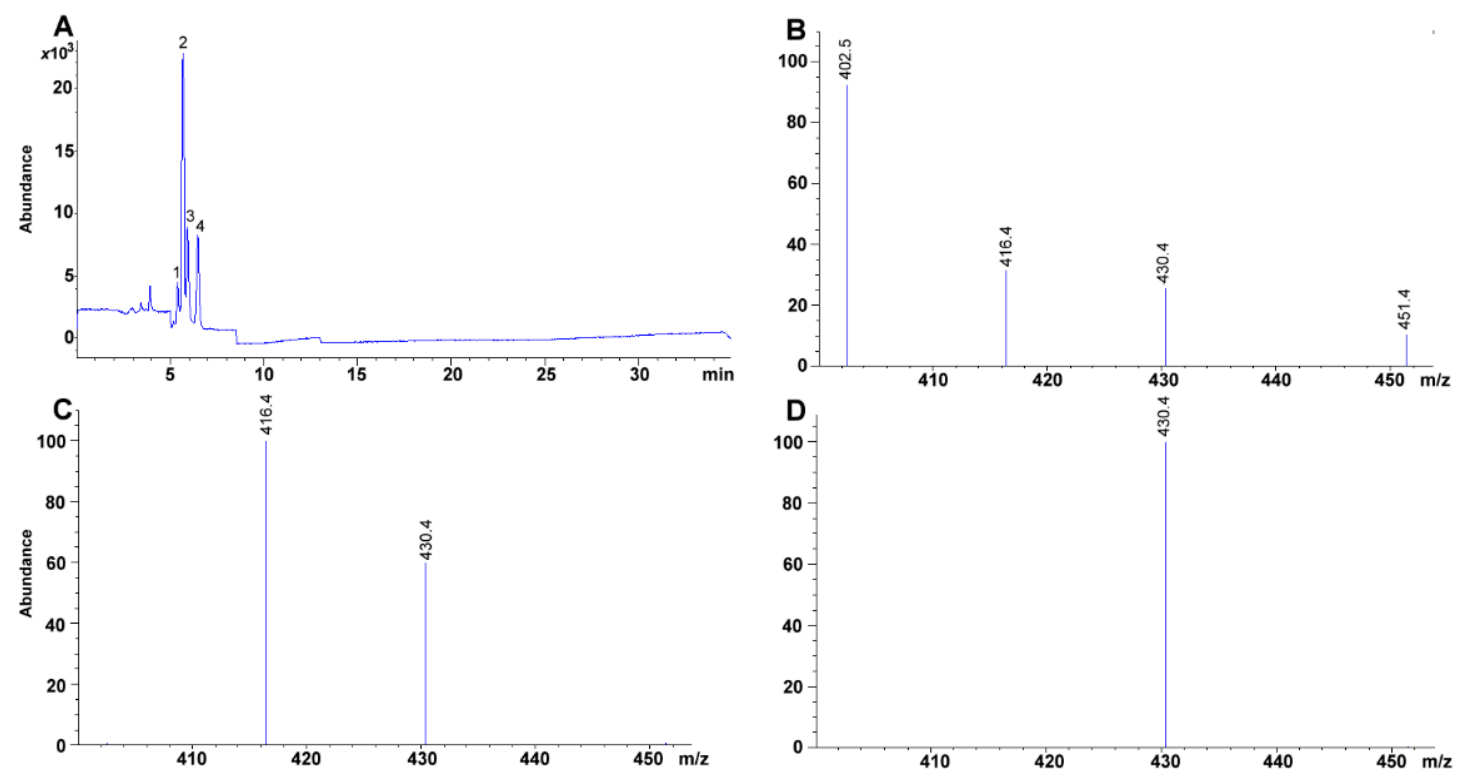

Figure 4. (A) Chromatogram of a mixture of tocopherols (W530066 70, 13, 523, $105 \mathrm{mg} \mathrm{g}^{-1}$ for $\alpha$ (peak 4), $\beta$ - (peak 2), $\gamma$ - (peak 3), and $\delta$-tocopherol (peak 1$)$, respectively). Selected $[\mathrm{M}+\mathrm{H}]^{+}$ion for (B) $\delta$-tocopherol $(402.1 \mathrm{~m} / \mathrm{z}),(\mathbf{C}) \beta / \gamma$-tocopherol $(416.4 \mathrm{~m} / \mathrm{z})$, and (D) $\alpha$-tocopherol $(430.4 \mathrm{~m} / \mathrm{z})$. Selected ion monitoring (SIM) at 700, 130, 5230, $1050 \mu \mathrm{g} \mathrm{mL}-1$.

\subsection{Method Application in Real Samples}

Simmonds variety characterizes itself for having an oblong oval to pear-shape large-sized fruit of light green-colored smooth skin, and a seed of medium size, usually tight. Meanwhile, Guatemala has a medium to large size and nearly round shape, smooth, thick, granular, and green skin with a small seed. Finally, Hass fruit possesses an ovoid to pear shape, is of medium size, with tough, leathery, pebbled, thin, dark purple to black (when ripe) skin, with a small seed [30,56].

We found in avocado both non-provitamin A (lutein and zeaxanthin) and provitamin A ( $\beta$-carotene and $\beta$-cryptoxanthin) carotenoids [57] (Table 6). All carotenoids encountered have been previously identified for the fruit (see, for example, $[11,20,21,23,28,29])$. Our data indicated that, overall, all three varieties of avocado exhibited concentrations, of carotenoids and vitamins, in line (except for provitamin A carotenoids which levels were considerably higher for Costa Rican avocadoes) with those reported elsewhere [28]. Considering the above, Costa Rican avocado would supply to diet retinol equivalents [58] ranging from 1085.21 to $425.01 \mu \mathrm{g}$ on a dry weight basis. Though three different varieties of avocado have been examined, it should be clear that any number of factors can affect the concentrations of such molecules, including edaphoclimatic conditions, genotypic differences, and nutritional status of the plants [59]. Hass and Guatemala varietals showed a somewhat similar profile for both fat-soluble vitamins as carotenoids. Meanwhile, the Simmonds variety showed higher levels for almost all analytes tested (except for lutein) (Table 6 ). Interestingly, the $\delta / \alpha$ ratio of isomers is close to 1 for all varieties (i.e., $0.75-1.22$ ). 
Table 6. Fat-soluble vitamins and carotenoids obtained from Costa Rican avocadoes.

\begin{tabular}{cccc}
\hline \multirow{2}{*}{ Compound } & Simmonds & Hass & Guatemala \\
\cline { 2 - 4 } & \multicolumn{2}{c}{ Concentration, $\mathbf{~ m g / 1 0 0 ~ g ~ d r y ~ W e i g h t ~ B a s i s ~}$} \\
\hline Ergocalciferol & $1.84 \pm 0.18$ & $0.31 \pm 0.16$ & $0.53 \pm 0.33$ \\
Cholecalciferol & $119.50 \pm 1.20$ & $103.50 \pm 15.50$ & $108.50 \pm 33.40$ \\
$\delta$-tocopherol & $42.48 \pm 7.96$ & $8.31 \pm 1.63$ & $6.16 \pm 2.88$ \\
$\gamma$-tocopherol & $4.81 \pm 0.48$ & $2.42 \pm 0.37$ & $0.92 \pm 0.16$ \\
$\alpha$-tocopherol & $34.80 \pm 14.50$ & $8.16 \pm 0.97$ & $8.20 \pm 3.67$ \\
Astaxanthin & $2.23 \pm 0.14$ & $0.64 \pm 0.23$ & $0.98 \pm 0.55$ \\
Lutein & $6.41 \pm 2.03$ & $15.13 \pm 8.66$ & $10.79 \pm 2.77$ \\
Zeaxanthin & $0.03 \pm 0.01$ & $0.02 \pm 0.01$ & $0.02 \pm 0.01$ \\
$\beta$-cryptoxanthin & $6.10 \pm 1.39$ & $3.37 \pm 0.20$ & $1.66 \pm 0.85$ \\
$\beta$-carotene & $3.43 \pm 2.09$ & $2.28 \pm 1.56$ & $1.71 \pm 0.21$ \\
\hline
\end{tabular}

\subsection{Method Application in Other Samples}

As stated before, no standard reference material is available for avocado. However, as a quality control material, we subjected our method to infant formula to further assess method accuracy. We obtained values according to the provider, and no appreciable matrix effects were observed for this food either (Figure 5A). Also, our method showed promise to extrapolate to other matrices, especially fruits. Unambiguous signals of several vitamins of interest can be seen when a chloroform extract obtained from green tomatoes was injected (Figure 5B).
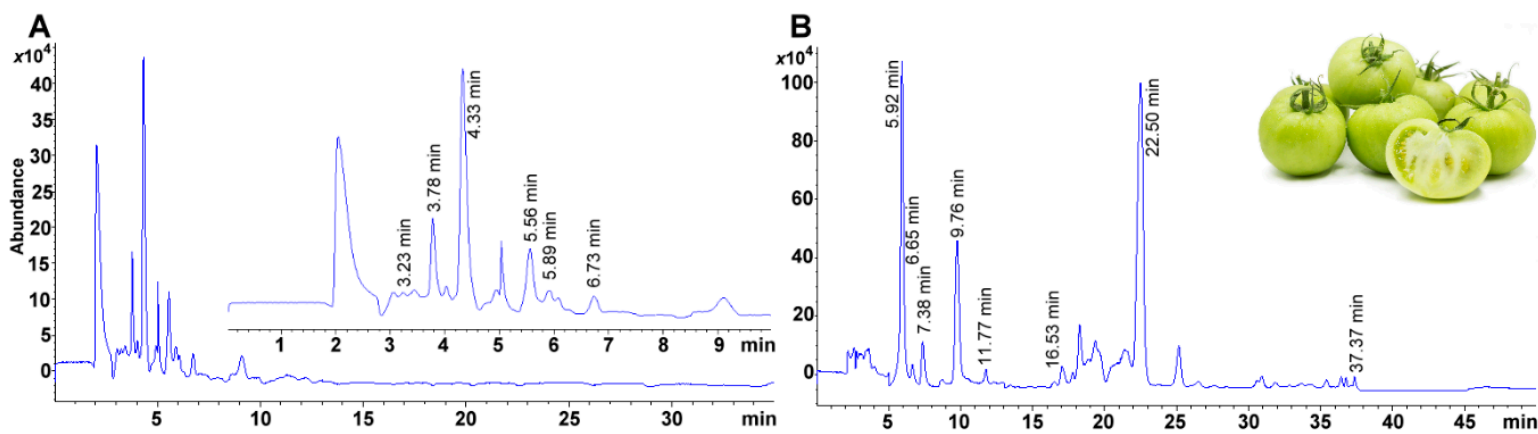

Figure 5. (A) Infant formula with certified values for fat-soluble vitamins. The box shows the amplification of the region from 1 to $10 \mathrm{~min}$ of the said chromatogram. FAPAS ${ }^{\circledR}$ reference material TYG009RM. Vitamin A, vitamin $\mathrm{D}_{3}$, and vitamin E at $508 \pm 12,7.16 \pm 0.33$, and 10,900 $\pm 400 \mu \mathrm{g} / 100 \mathrm{~g}$. (B) Non-saponified sample of green tomatoes extracted after mechanical shearing and chloroform extraction and analyzed using the proposed method.

\section{Materials and Methods}

\subsection{Reagents}

tert-Butyl methyl ether (99\%, catalog 34875, MTBE, chromatographic grade), methanol ( $\geq 99.9 \%$, catalog 646377, $\mathrm{MeOH}$, chromatographic grade) and potassium hydroxide (ACS reagent, catalog 1050210250) were acquired from Merck Millipore (Burlington, MA, USA). Retinyl acetate (catalog 46958), retinyl palmitate (catalog 46959-U), cholecalciferol (catalog C9774), ergocalciferol (catalog 47768), 3-phytylmenadione catalog (95271), $\alpha$-tocopherol (catalog 47783), $\delta$-tocopherol (catalog 47784), $\gamma$-tocopherol (catalog T1782), tocopherols (mixed, W530066), lutein (catalog 071068), $\beta$-carotene (catalog C4582), $\beta$-cryptoxanthin ( $\geq 97 \%$, catalog C6368), zeaxanthin (catalog 14681), all-trans-astaxanthin (catalog 41659), and lycopene (catalog 75051) from Sigma-Aldrich (unless stated otherwise, all standards were of analytical grade, St. Louis, MO, USA). Chloroform (ACS reagent, catalog 366919), ethanol (200 proof, ACS reagent, $\geq 99.5 \%, 459844$ ), 2-propanol (HPLC Plus, 650447), pyrogallol (ACS 
reagent, $\geq 99 \%$, catalog 16040), and sodium sulfate (anhydrous, granular, free-flowing, Redi-Dri ${ }^{\mathrm{TM}}$, ACS reagent, $\geq 99 \%$, catalog 798592) were also acquired from Sigma-Aldrich.

\subsection{Sample Treatment and Preparation}

Three different varieties of avocado collected from Costa Rica farms, two varietals from low and one highland, i.e., Simmonds (from 0 to $1000 \mathrm{~m}$ amsl), Guatemala (from 600 to $1500 \mathrm{~m}$ amsl), and Hass (from 1000 to $2000 \mathrm{~m}$ amsl), respectively [30,56]. Three batches of each variety were analyzed, each with eight days of maturation. A previously homogenized subsample $(2 \mathrm{~g})$ of freeze-dried material was weighed, and chloroform ( $20 \mathrm{~mL}$, ACS reagent, Sigma-Aldrich 366919) was added. After that, the mixture was stirred continuously (30 min) using an Ultraturrax ${ }^{\circledR}(\mathrm{T} 25$, at $7500 \mathrm{rpm}$, IKA Works Staufen, Germany). The remnant suspension was centrifuged, and the supernatant liquid recollected. The extraction procedure was repeated twice. The solvent was evaporated using a rotary evaporator (Multivapor ${ }^{\mathrm{TM}}$ P-6, Büchi, Flawil, Switzerland) until the lipid fraction was attained, which was then processed immediately for saponification.

\subsection{Optimization of Saponification Conditions}

An additional experiment was performed to enhance the recovery of the analytes of interest during the saponification reaction. The experimental design consisted of maintaining constant reaction time $(1 \mathrm{~h})$, the concentration of radical protection agent $(0.1 \mathrm{~g} / 100 \mathrm{~mL})$, and the extraction solvent (hexane). Base concentration was contrasted ( 1 vs. 2 mol KOH L ethanol ${ }^{-1}$ [43] for each temperature), and the temperature was progressively increased $\left(60,80\right.$, and $\left.95^{\circ} \mathrm{C}\right)$. The conditions that rendered the most recoveries were selected to process the samples.

\subsection{Sample Saponification}

A small portion of the fat fraction $(0.3 \mathrm{~g})$ was weighed and quantitatively transferred to a conical centrifuge tube (50 mL, CLS430829, polypropylene, Corning ${ }^{\circledR}$, New York, USA). Afterward, $\mathrm{KOH}$ in ethanol $\left(1 \mathrm{mmol} \mathrm{mL}^{-1}\right)$ and containing pyrogallol $(0.1 \mathrm{~g} / 100 \mathrm{~g})$ was added $(10 \mathrm{~mL})$. The mixture was let to saponify (during $1 \mathrm{~h}$ at $80^{\circ} \mathrm{C}$ ) in a heat bath (1229U55, Boekel Scientific, Feasterville, PA, USA). The resulting mixture was let to cool to room temperature and transferred to a Squibb separatory funnel (PYREX ${ }^{\circledR}, 250 \mathrm{~mL}$, Corning ${ }^{\circledR}$ 6402). The above ethanol/aqueous layer was subjected to a liquid-liquid extraction using hexane. The extraction procedure was repeated twice. The totality of the organic solvent layer was then collected and filtered through sodium sulfate (used as a desiccant). The resulting solution was evaporated to dryness under a nitrogen flow (Ultra-High Pure Nitrogen was purchased from Praxair Technology Inc., Danbury, Connecticut, USA) and then reconstituted with MTBE (1 mL) and 2-propanol $(1 \mathrm{~mL})$ used at the start of the chromatographic separation and transferred to an HPLC vial (Agilent technologies, Santa Clara, CA, USA).

\subsection{Stationary Phase and Selection of Chromatographic Conditions}

The major obstacle in vitamin separation is the segregation of isomers. With this in mind, as a starter setup, we used a mobile phase based on $\mathrm{MeOH}$ and water using an eight carbon-based alkyl stationary phase $\left(0.75 \mathrm{~mL} \mathrm{~min}^{-1}\right.$, Eclipse Plus $\mathrm{C}_{8}, 4.6 \mathrm{~mm} \mathrm{ID} \times 150 \mathrm{~mm}, 3 \mu \mathrm{m}$, Agilent Technologies). As the resolution was insufficient, a $\mathrm{C}_{18}$ column was selected, and only flow was modified ( $1 \mathrm{~mL} \mathrm{~min}^{-1}$, Eclipse Plus $C_{18}, 4.6 \mathrm{~mm}$ ID $\times 150 \mathrm{~mm}, 3 \mu \mathrm{m}$, Agilent Technologies). Then we substituted the column for a $\mathrm{C}_{30}$, removed water, and used a less polar solvent in acetonitrile and 2-propanol, reducing yet again the solvent flow $\left(0.5 \mathrm{~mL} \mathrm{~min}^{-1}\right)$ (Table 1). Finally, retaining a similar proportion of $\mathrm{MeOH}$, we substituted acetonitrile and isopropanol for MTBE. The $\mathrm{C}_{30}$ column was kept as it already had excellent capabilities reported for highly lipophilic compounds (e.g., carotenoids) [39]. 


\subsection{Chromatographic Conditions}

All assays performed using an Agilent Technologies LC/MS system equipped with 1260 infinity quaternary pump (61311C), column compartment (G1316A), automatic liquid sampler modules (ALS, G7129A) and a 6120-single quadrupole mass spectrometer with electrospray ionization ion source (Agilent Technologies, Santa Clara, CA, USA). Gradient elution was used to separate all the compounds. The solvent gradient was optimized using $\mathrm{MeOH}$ (solvent $\mathrm{A}$ ) and MTBE (solvent $\mathrm{B}$ ), both acidified with formic acid $(0.1 \mathrm{~mL} / 100 \mathrm{~mL})$. Solvent proportions were set as follows: at $0 \mathrm{~min} 80 \% \mathrm{~A}$, at $5 \mathrm{~min} 80 \%$ $\mathrm{A}$, at $7 \min 73 \% \mathrm{~A}$, at $15 \min 62.5 \% \mathrm{~A}$, at $20 \min 62.5 \% \mathrm{~A}$, at $30 \min 45 \% \mathrm{~A}$, at $35 \min 10 \% \mathrm{~A}$, at $40 \mathrm{~min}$ $10 \% \mathrm{~A}$, at $45 \mathrm{~min} 80 \% \mathrm{~A}$ and $50 \mathrm{~min} 80 \% \mathrm{~A}$. Flow rate was kept constant at $0.6 \mathrm{~mL} \mathrm{~min}^{-1}$. Injection volume was held at $10 \mu \mathrm{L}$. The column compartment was held at a temperature of $10.0 \pm 0.8^{\circ} \mathrm{C}$. Considering the need for the separation of structurally similar compounds, a 30-carbon alkyl chain based chromatographic column was used to achieve the analytical separation (YMC Carotenoid, $4.6 \mathrm{~mm}$ ID $\times 150 \mathrm{~mm}$, S-3 $\mu \mathrm{m}$, YMC Co., Ltd., Kyoto, Japan).

\subsection{MS Detection System Conditions}

The fragmentor was initially cycled to assess the voltage (from 20 to $300 \mathrm{~V}$ ) that rendered the highest sensitivity for the compounds; omitting column interaction (Figure 6A). Afterward, total ion chromatographs (TIC) allowed us to obtain the MS spectra for each of the compounds (scan mode using a mass range and detector gain set to $50-750 \mathrm{~m} / \mathrm{z}$, and 10.00, respectively) (Figure 6B,C). Each TIC was used to identify the molecular ion signal. Drying gas, nebulizer pressure, drying gas temperature, and capillary voltage was set, respectively, to $12.0 \mathrm{~L} \mathrm{~min}^{-1}, 50 \mathrm{psi}, 350{ }^{\circ} \mathrm{C}, 4000 \mathrm{~V}$ for positive ion mode electrospray ionization $\left(\mathrm{ESI}^{+}\right)$. Selected ion monitoring was used to corroborate each compound identity, remove interferences and improve sensitivity (SIM mode with peak width and cycle time set to $0.05 \mathrm{~min}$, and $0.30 \mathrm{~s} \mathrm{cycle}^{-1}$, respectively) (Table 2, Figure $6 \mathrm{D}$ ).
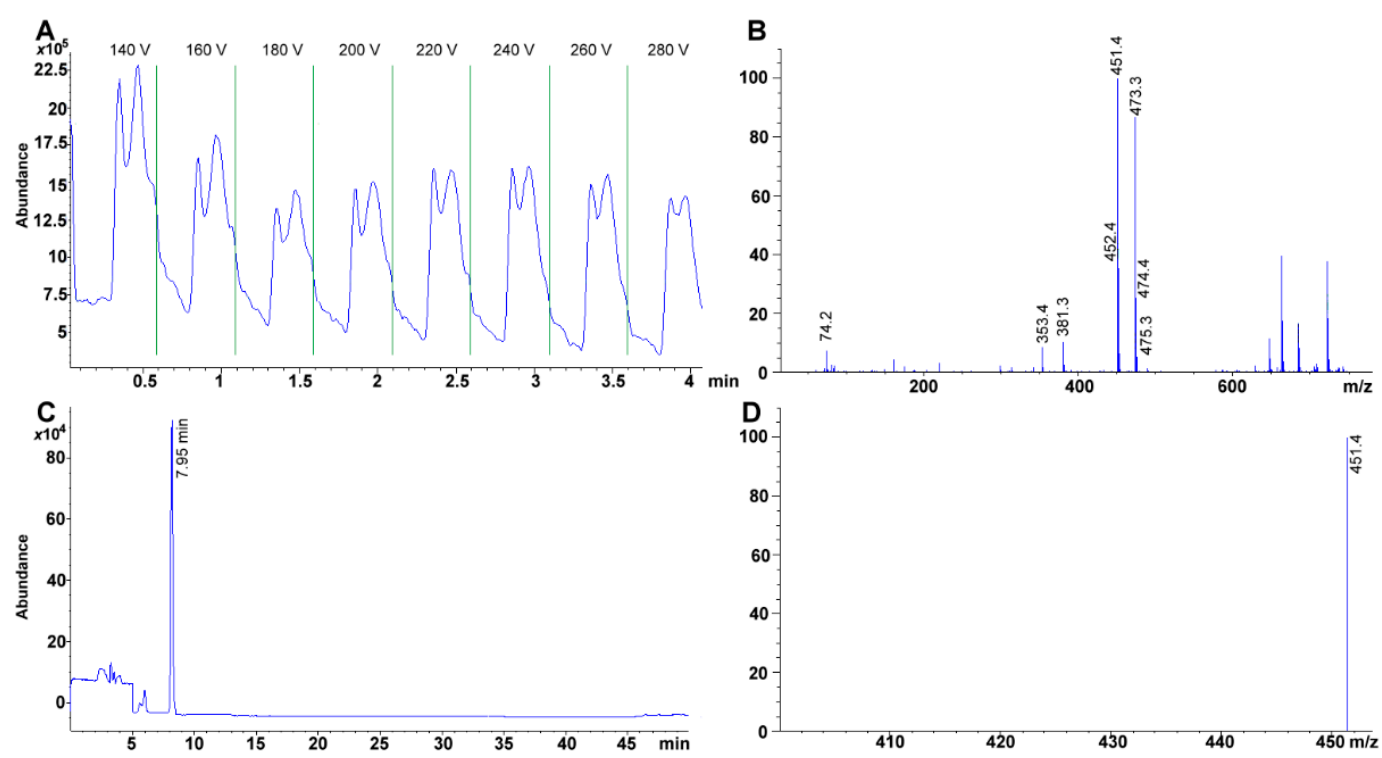

Figure 6. Example of the voltage cycling for phylloquinone to obtain the most sensitivity, data obtained at $100 \mu \mathrm{g} \mathrm{mL}^{-1}$. (A) A parameter was selected where the signal delivered the most area under the curve. (B) Mass spectra obtained from a total ion chromatogram for phylloquinone at $100 \mu \mathrm{g} \mathrm{mL}^{-1}$. Fragmentation as follows (molar mass $\left.450.7 \mathrm{~g} \mathrm{~mol}^{-1}\right)$ : $473.3\left([\mathrm{M}+\mathrm{K}]^{+}\right), 451.4\left([\mathrm{M}+\mathrm{H}]^{+}\right), 381.3$ $\left(\left[\mathrm{C}_{26} \mathrm{H}_{35} \mathrm{O}_{2}\right]^{\bullet}\right), 353.4\left(\left[\mathrm{C}_{24} \mathrm{H}_{30} \mathrm{O}_{2}\right]^{2 \bullet}\right), 225\left(\left[\mathrm{C}_{15} \mathrm{H}_{13} \mathrm{O}_{2}\right]^{\bullet}\right.$ and partial alkyl isoprenoid chain $\left.\left[\mathrm{C}_{16} \mathrm{H}_{33}\right]^{\bullet}\right)$, and 186 (quinone ring, $\left[\mathrm{C}_{12} \mathrm{H}_{9} \mathrm{O}_{2}\right]^{\bullet}$ ) $\mathrm{m} / z$ [60]. (C) Chromatogram for phylloquinone was obtained using the selected $[\mathrm{M}+\mathrm{H}]^{+} 451 \mathrm{~m} / z$ and (D) selected ion monitoring (SIM) for the target analyte at $20 \mu \mathrm{g} \mathrm{mL}^{-1}$. 
Sensitivity is greatly improved using a SIM targeted scan. For example, the same standard $34.4 \mathrm{mg}$ phylloquinone $\mathrm{L}^{-1}$ in TIC throws 37870 vs. 457785 area under the curve in SIM. Furthermore, within curve sensitivity reaches only $24.1 \mathrm{mg} \mathrm{L}^{-1}$ for TIC while the signal for $4.31 \mathrm{mg} \mathrm{L}^{-1}$, in SIM, is still appreciable (i.e., 80471 area under the curve, $0.54 \mathrm{mg} \mathrm{L}^{-1}$ within curve sensitivity) (Figure 7A,B). Absolute sensitivity to vitamin $\mathrm{K}$ increases almost 50 fold (24.1/0.54). For carotenoids, the change is more dramatic as $100 \mathrm{mg} \mathrm{L}^{-1}$ standard has to be prepared in TIC for a detectable signal while $0.136 \mathrm{mg}$ $\mathrm{L}^{-1}$ is still noticeable (Figure $2 \mathrm{~B}$ ), which represents ca. 750-fold in increased sensitivity.
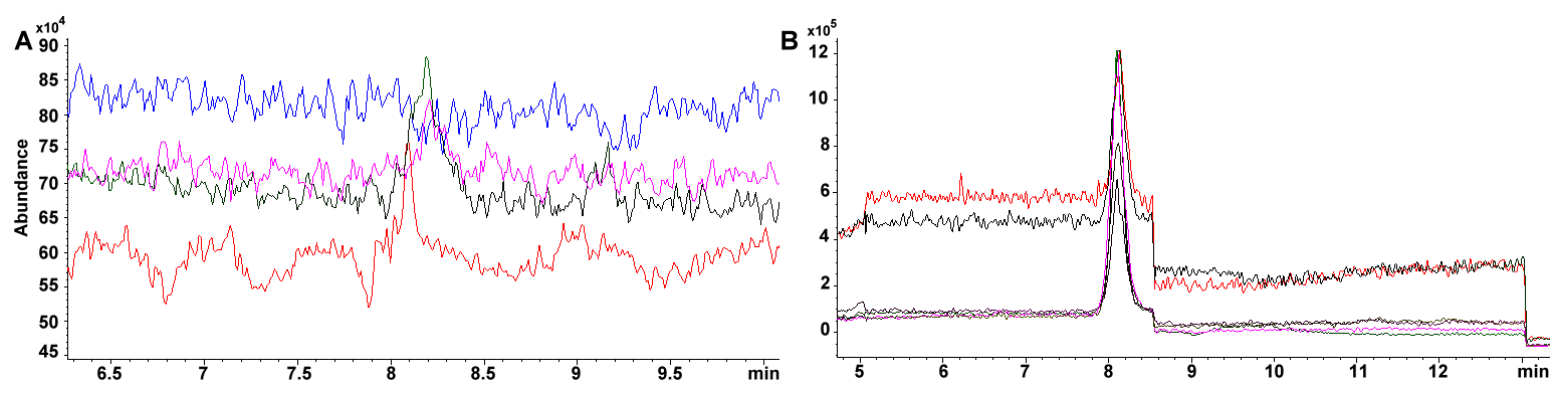

Figure 7. Calibration curve and sensitivity comparison using (A). TIC and SIM modes for vitamin $\mathrm{K}_{1}$ both signals tested at $137.8,68.9,34.4,17.2,8.61$, and $4.31 \mathrm{mg} \mathrm{L}^{-1}$ and using a fragmenter of $140 \mathrm{~V}$. No signal is noticeable at $17.2 \mathrm{mg} \mathrm{L}^{-1}$ for TIC (blue line in panel (A)). Meanwhile, a calibration curve is easily constructed in SIM mode with the lowest point in $4.31 \mathrm{mg} \mathrm{L}^{-1}$ (purple line panel (B)).

Retention times and mass spectra were collected by the centroid of the chromatographic peak. Quantitation was carried out by comparing the peak areas found in the samples with those of standard solutions. The identification and quantification of targeted compounds analyzed by LC-ESI ${ }^{+}-\mathrm{MS}_{\text {were }}$ performed using OpenLab Chemstation C.01.07 (Agilent Technologies) for the processing of MS data sets. Confirmation of target analytes was based on the retention time $( \pm 0.2 \mathrm{~min}$ as accepted time deviation), measurement of the molecular ion in a specific timeframe (Table 2).

\subsection{Statistical Analysis}

Calibration curves parameters (i.e., slopes and intercepts), coefficients of determination, limits of detection, and standard errors were computed as a linear fit model using SAS JMP 13 (Marlow, Buckinghamshire, England). An ANOVA with a post-hoc Dunnet test was used to assess differences among treatments during the optimization of the conditions during saponification. Concentrations obtained using the conditions $1 \mathrm{~h}$ and $1 \mathrm{mmol} \mathrm{KOH} \mathrm{mL}$ ethanol ${ }^{-1}$ at $80^{\circ} \mathrm{C}$, were used as the control parameters; the test considered if the data was below the control, with $\alpha=0.05$ significance level. The statistical analysis was performed using IBM SPSS ${ }^{\circledR}{ }^{\circledR}$ Statistics 23 (Armonk, NY, USA).

\section{Conclusions}

The proposed method was regarded as a greener option by replacing chlorinated solvents and allowed two nutritionally relevant families of bioactive compounds (i.e., carotenoids and fat-soluble vitamins) to be analyzed together (which is not usually the case) and offered an adequate resolution in the case of tocopherol and calciferol isomers to improve their differential quantification. We obtained an accurate, sensitive, robust, and highly specific multi-analyte method that was successfully applied to avocadoes, a fruit of high economic value, of dietary interest, and a staple of Latin-American cuisine. The use of separation based entirely on organic solvents and the $C_{30}$ column retention capability rendered a versatile method that can facilitate the incorporation of other pigments that have been reported present in avocado fruit (e.g., neoxanthin, trollichrome, chrysanthemaxanthin) $[14,21]$ to further extend its chemical characterization. Saponification was paramount in the recovery of fat-soluble compounds. Therefore, optimized conditions should be assessed for each matrix to be tested. The method may be extended to evaluate fat-soluble vitamins and carotenoids in other matrices. 
Mass spectrometry was a crucial tool in enabling the discrimination of structurally related compounds (e.g., all three tocopherol isomers could be easily accounted for in avocado).

Author Contributions: Conceptualization, F.G.-C., G.A., and C.C.-H.; methodology, F.G.-C. and C.C.-H.; software, F.G.-C. and C.C.-H.; validation, F.G.-C., G.A., A.C., and C.C.-H.; formal analysis, F.G.-C., G.A., A.C., and C.C.-H.; investigation, F.G-C.; resources, F.G.-C., G.A., and C.C.-H.; data curation, C.C.-H., F.G-C., and G.A; writing - original draft preparation, F.G.-C.; writing—review and editing, F.G.-C., G.A., A.C., C.C.-H.; visualization, F.G.-C.; supervision, F.G.-C. and C.C-H; project administration, F.G.-C. and C.C-H.; funding acquisition, C.C-H.

Funding: This research received no external funding except for the APC, which was funded by the Vice Provost Office for Research of the Universidad de Costa Rica.

Acknowledgments: Laura Arroyo is acknowledged for acquiring the avocado samples and preliminary integration of a few avocado samples and María Sabrina Sánchez for their suggestions, revising the manuscript and for language editing.

Conflicts of Interest: The authors declare no conflict of interest.

\section{References}

1. Arias, F.; Montoya, C.; Velásquez, O. Dinámica del Mercado mundial de aguacate. Rev. Virtual Univ. Católica Del Norte 2018, 55, 22-35. [CrossRef]

2. Xiong, B.; Song, Y. Big data and dietary trend: The case of avocado imports in China. J. Int. Food Agribus. Mark. 2018, 30, 343-354. [CrossRef]

3. Macías Macías, A. Mexico in the International Avocado Market. Rev. De Cienc. Soc. (RCS) 2011, 17, 517-532.

4. Díaz Vasquez, J.; Ardila Lopez, C.; Guerra Aranguren, M.A. Case Study on the Eligibility of Colombian Hass Avocado in the US Market: Opportunities in East Asia. Online J. Mundo Asia Pac. 2019, 8, 5-27.

5. PROCOMER [Promotora de Comercio Exterior de Costa Rica]. Anuario Estadístico 2017. PROCOMER: San José, Costa Rica, 2018. Available online: https:/procomer.com/en/estudios/anuario_estadistico_2018 (accessed on 25 August 2019).

6. Butnariu, M. Methods of analysis (extraction, separation, identification, and quantification) of carotenoids from natural products. J. Ecosys. Ecograph. 2016, 6, 2. [CrossRef]

7. Unlu, N.Z.; Bohn, T.; Clinton, S.K.; Schwartz, S.J. Carotenoid Absorption from Salad and Salsa by Humans Is Enhanced by the Addition of Avocado or Avocado Oil. J. Nutr. 2005, 135, 431-436. [CrossRef]

8. Brown, M.J.; Ferruzzi, M.G.; Nguyen, M.L.; Cooper, D.A.; Schwartz, S.J.; White, W.S. Carotenoid bioavailability is higher from salads ingested with full-fat than with fat reduced salad dressings as measured with electrochemical detection. Am. J. Clin. Nutr. 2004, 80, 396-403. [CrossRef]

9. Desmarchelier, C.; Borel, P. Overview of carotenoid bioavailability determinants: From dietary factors to host genetic variations. Trends Food Sci Technol. 2017, 69, 270-280. [CrossRef]

10. Meyer, M.D.; Landahl, S.; Donetti, M.; Terry, L.A. Avocado. In Health-Promoting Properties of Fruits and Vegetables, 1st ed.; Terry, L.A., Ed.; CABI: Oxfordshire, UK, 2011; pp. 27-50.

11. Dreher, M.L.; Davenport, A.J. Hass avocado composition and potential health effect. Crit. Rev. Food Sci. Nutr. 2013, 53, 738-750. [CrossRef]

12. Fulgoni, V.L.; Dreher, M.L.; Davenport, A.J. Avocado consumption is associated with better diet quality and nutrient intake, and lower metabolic syndrome risk in US adults: Results from the National Health and Nutrition Examination Survey (NHANES) 2001-2008. Nutr. J. 2013, 12. [CrossRef]

13. Comerford, K.B.; Ayoob, K.T.; Murray, R.D.; Atkinson, S.A. The role of Avocados in Maternal Diets during the periconceptional Period, Pregnancy, and Lactation. Nutrients 2016, 8, 313. [CrossRef] [PubMed]

14. Duarte, P.F.; Chaves, M.A.; Borges, C.D.; Mendoca, C.R.B. Avocado: Characteristics, Health Benefits and Uses. Ciência Rural 2016, 46, 747-754. [CrossRef]

15. Noorul, H.; Nesar, A.; Zafar, K.; Khalid, M.; Zeeshan, A.; Vartika, S. Health benefits and pharmacology of Persea americana mill. (Avocado). Int. J. Res. Pharmacol. Pharmacother. 2016, 5, 132-141.

16. Scott, T.M.; Rasmussen, H.M.; Chen, O.; Johnson, E.J. Avocado Consumption Increases Macular Pigment Density in Older Adults: A Randomized, Controlled Trial. Nutrients 2016, 9, 919. [CrossRef] 
17. Lu, Q.-Y.; Arteaga, J.R.; Zhang, Q.; Huerta, S.; Go, V.L.W.; Heber, D. Inhibition of prostate cancer cell growth by an avocado extract: Role of lipid-soluble bioactive substances. J. Nutr. Biochem. 2005, 16, 23-30. [CrossRef]

18. Gross, J.; Gabai, M.; Lifshitz, A. The carotenoid of the avocado pear. Persea americana, Nabal Variety. J. Food Sci. 1972, 37, 589-591. [CrossRef]

19. Moran, N.E.; Johnson, E.J. Closer to clarity on the effect of lipid consumption on fat-soluble vitamin and carotenoid absorption: Do we need to close in further? Am. J. Clin. Nutr. 2017, 106, 969-970. [CrossRef]

20. Grune, T.; Lietz, G.; Palou, A.; Catharine Ross, A.; Stahl, W.; Tang, G.; Thurnham, D.; Yin, S.; Bielaski, H.K. $\beta$-Carotene is an important vitamin A source for human. J. Nutr. 2010, 140, 2269S-2285S. [CrossRef]

21. Mardigan, L.P.; dos Santos, V.J.; da Silva, P.T.; Visentainer, J.V.; Gomes, S.T.M.; Matsuchita, M. Investigation of bioactive compounds from various avocado varieties (Persea americana Miller). Food Sci. Technol. 2018, 39 (Suppl. 1), 15-21. [CrossRef]

22. Ashton, O.B.O.; Wong, M.; McGhie, T.K.; Vather, R.; Wang, Y.; Requejo-Jakcman, C.; Ramankutty, P.; Woolf, A.B. Pigments in Avocado Tissue and Oil. J. Agric. Food Chem. 2006, 54, 10151-10158. [CrossRef]

23. Yano, M.; Kato, M.; Ikoma, Y.; Kawasaki, A.; Fukazawa, Y.; Sugiura, M.; Matsumo, H.; Oohara, Y.; Nagao, A.; Ogawa, K. Quantitation of Carotenoids in Raw and Processed Fruits in Japan. Food Sci. Technol. Res. 2005, 11, 13-18. [CrossRef]

24. Ramos, A. Phytochemical analysis of avocado seeds (Persea amerciana Mill., c.v. Hass), 1st ed.; Cuvillier Verlag: Göttingen, Germany, 2007; pp. 26-28.

25. Talabi, J.Y.; Osukoya, O.A.; Ajayi, O.O.; Adegoke, G.O. Nutritional and antinutritional compositions of processed Avocado (Persea americana Mill) seeds. Asian J. Plant. Sci. Res. 2016, 6, 6-12.

26. Khoo, H.-E.; Prasad, K.N.; Kong, K.-W.; Jiang, Y.; Ismail, A. Carotenoids and Their Isomers: Color Pigments in Fruits and Vegetables. Molecules 2011, 16, 1710-1738. [CrossRef]

27. Pérez-Gálvez, A.; Roca, M. Recent Developments in the Analysis of Carotenoids by Mass Spectrometry. In Progress in Carotenoid Research, 1st ed.; Zepka, L.Q., Ed.; IntechOpen Limited: London, UK, 2018; pp. 17-44.

28. Lu, Q.-Y.; Zhang, Y.; Wang, Y.; Wang, D.; Lee, R.-P.; Gao, K.; Byrns, R.; Heber, D. California Hass Avocado: Profiling of Carotenoids, Tocopherol, and Fat Content during Maturation and from Different Growing Areas. J. Agric. Food Chem. 2009, 57, 10408-10413.

29. Jacobo-Velázquez, D.A.; Hernández-Brenes, C. Stability of avocado paste carotenoids as affected by high hydrostatic pressure processing and storage. Innov. Food Sci. Emerg. Technol. 2012, 16, 121-128. [CrossRef]

30. Morera, J.A. El Aguacate, 1st ed.; Unidad de Recursos Fitogenéticos CATIE/GTZ: Turrialba, Costa Rica, 1983; pp. 10-19.

31. McGraw, K.J.; Toomey, M.B. Carotenoid accumulation in the tissues of Zebra Finches: Predictors of Intergumentary Pigmentation and Implication for Carotenoid Allocation strategies. Physiol. Biochem. Zool. 2010, 83, 97-109. [CrossRef]

32. Taygerly, J.P.; Miller, L.M.; Yee, A.; Peterson, E.A. A convenient guide to help select replacement solvents for dichloromethane in chromatography. Green Chem. 2012, 14, 3020-3025. [CrossRef]

33. Sander, L.C.; Sharpless, K.E.; Craft, N.E.; Wise, S.A. Development of Engineered Stationary Phase for the Separation of Carotenoid Isomers. Anal. Chem. 1994, 66, 1667-1674. [CrossRef]

34. Van Breemer, R.B.; Huang, C.-H. High-performance liquid chromatography-electrospray mass spectrometry of retinoids. FASEB J. 1996, 10, 1098-1101. [CrossRef]

35. Fraser, P.D.; Enfissi, E.M.A.; Goodfellow, M.; Eguchi, T.; Bramley, P.M. Metabolite profiling of plant carotenoids using the matrix-assisted laser desorption ionization time-of-flight mass spectrometry. Plant J. 2007, 49, 552-564. [CrossRef]

36. $\mathrm{Xu}, \mathrm{F}$; Yuan, Q.P.; Dong, H.R. Determination of lycopene and $\beta$-carotene by high-performance liquid chromatography using sudan I as internal standard. J. Chrom. B 2006, 838, 44-49. [CrossRef] [PubMed]

37. Ding, J.; Hui, B. Quantification of all-trans-lycopene and $\beta$-carotene from tomato and its products by internal standard method on $\mathrm{C}_{30}$-HPLC. Food Sci. 2010, 31, 348-354.

38. Tan, J.; Leong Neo, J.G.; Setiawati, T.; Zhang, C. Determination of carotenoids in human serum and breast milk using high performance liquid chromatography coupled with a Diode Array Detector (HPLC-DAD). Separations 2017, 4, 19. [CrossRef] 
39. Van Breemen, R.B. Liquid chromatography/mass spectrometry of carotenoids. Pure Appl. Chem. 1997, 69, 2061-2066.

40. Borman, P.; Elder, D. Q2 (R1) Validation of Analytical Procedures. In ICH Quality Guidelines: An Implementation Guide; John Wiley \& Sons, Inc.: Hoboken, NJ, USA, 2017; pp. 127-166.

41. Kumar Saini, R.; Keum, Y.-S. Carotenoid extraction methods: A review of recent developments. Food Chem. 2018, 240, 90-103. [CrossRef]

42. Binnal, P.; Nirguna Babu, P. Production of high biodiesel through direct saponification of wet biomass of Chlorella protothecoides in a low cost microwave reactor: Kinetic and thermodynamic studies. Korean J. Chem. Eng. 2017, 34, 1027-1036. [CrossRef]

43. Li, T.; Xu, J.; Wu, H.; Wang, G.; Dai, S.; Fan, J.; He, H.; Xiang, W. A saponification method for chlorophyll removal from microalgae biomass as oil feedstock. Mar. Drugs 2016, 14, 162. [CrossRef]

44. Boon, C.S.; McClements, D.J.; Weiss, J.; Decker, E.A. Factors Influencing the Chemical Stability of Carotenoids. Crit. Rev. Food Sci. Nutr. 2010, 50, 515-532. [CrossRef]

45. Pénicaud, C.; Achir, N.; Dhuique-Mayer, C.; Dornier, M.; Bohuon, P. Degradation of $\beta$-carotene during fruit and vegetable processing or storage: Reaction mechanisms and kinetic aspects: A review. Fruits 2011, 66, 417-440. [CrossRef]

46. Hadjal, T.; Dhuique-Mayer, C.; Madani, K.; Dornier, M.; Achir, N. Thermal degrdation kinetics of xanthophylls from blood orange in model and real food systems. Food Chem. 2013, 138, 2442-2450. [CrossRef]

47. Aparicio-Ruiz, R.; Mínguez-Mosquera, M.; Gandul-Rojas, B. Thermal degradation kinetics of lutein, $\beta$-carotene and $\beta$-cryptoxanthin. J. Food Comp. Anal. 2011, 24, 811-820. [CrossRef]

48. Silva Fernades, A.; Casagrande do Nascimento, T.; Jacob-Lopes, E.; Vera de Roso, V.; Queiroz Zepka, L. Carotenoids: A Brief Overview on Its Structure, Biosynthesis, Synthesis, and Applications. In Progress in Carotenoid Research, 1st ed.; Queiroz Zepka, L., Jacob-Lopes, E., Vera de Roso, V., Eds.; IntechOpen: London, UK, 2018; pp. 1-15.

49. Li, D.; Xiao, Y.; Zhang, Z.; Liu, C. Light-induced oxidation and isomeration of all-trans- $\beta$-cryptoxanthin in a model system. J. Photochem. Photobiol. B Biol. 2015, 142, 51-58. [CrossRef] [PubMed]

50. AOAC [Association of Official Analytical Chemists]. AOAC Guidelines for Single Laboratory Validation of Chemical Methods for Dietary Supplements and Botanicals. 2002. Available online: https://www.aoac.org/ aoac_prod_imis/AOAC_Docs/StandardsDevelopment/SLV_Guidelines_Dietary_Supplements.pdf (accessed on 25 August 2019).

51. Scheppele, S.E.; Mitchum, R.K.; Rudolph, C.J.; Kinneberg, K.F.; Odell, G.V. Mass Spectra of Tocopherols. Lipids 1971, 7, 297-304. [CrossRef]

52. Djoumbou-Feunang, Y.; Pon, A.; Karu, N.; Zheng, J.; Li, C.; Arndt, D.; Gautam, M.; Allen, F.; Wishart, D.S. CFM-ID 3.0: Significanlty improved ESI-MS/MS prediction and compound identification. Metbolites 2019, 9, 72. [CrossRef]

53. Rivera, S.M.; Christou, P.; Canela-Garyoa, R. Identification of carotenoids using mass spectrometry. Mass Spectrom. Rev. 2013, 9999, 1-20. [CrossRef]

54. Liigand, J.; Laaniste, A.; Kruve, A. pH effects on electrospray ionization efficiency. J. Am. Soc. Mass Spectrom. 2017, 28, 461-469. [CrossRef]

55. De Rosso, V.V.; Mercadante, A.Z. Identification and quantification of carotenoids, by HPLC-PDA_MS/MS, from Amazonian fruits. J. Agric. Food Chem. 2007, 55, 5062-5072. [CrossRef]

56. Morera, J.A. Caracterización agronómica de una colección de variedades de aguacate (Persea americana Miller) en la subestación fraijanes, Alajuela, Costa Rica. Rev. Agr. Trop. 2004, 34, 19-25.

57. Toti, E.; Oliver Chen, C.-Y.; Palmery, M.; Villañ Valencia, D.; Peluso, I. Non-Provitamin A and Provitamin A Carotenoids as Inmunomodulators: Recommneded Diatary Allowance, Therapeutic Index, or Personalized Nutrition? Oxidative Med. Cell. Longev. 2018, 2018. [CrossRef]

58. Aremu, S.O.; Nweze, C.C. Determination of vitamin content form selected Nigerian fruits using spectrophotometric method. Bangladesh J. Sci. Ind. Res. 2017, 52, 153-158. [CrossRef]

59. Anary, P.M.; Santos, A.C. Nutritional Value of the Pulp of Different Sugar Apple Cultivars (Annona squamosa L.). In Nutritional composition of fruit cultivars, 1st ed.; Simmonds, M.S.J., Preedy, V.R., Eds.; Academic Press: Cambridge, MA, USA, 2015; p. 208. 
60. Marinova, M.; Lütjohann, D.; Westhofen, P.; Watzka, M.; Breuer, O.; Oldenburg, J. A validated HPLC Method for the determination of vitamin $\mathrm{K}$ in human serum-First Application in a Pharmocological Study. Open Clin. Chem. J. 2011, 4, 17-27. [CrossRef]

Sample Availability: Samples of the fat-soluble vitamins and carotenoids are available from the authors.

(C) 2019 by the authors. Licensee MDPI, Basel, Switzerland. This article is an open access article distributed under the terms and conditions of the Creative Commons Attribution (CC BY) license (http://creativecommons.org/licenses/by/4.0/). 